\title{
Toward a model of food sovereignty in Egypt and Tunisia
}

\author{
Review by Jennifer R. Shutek, New York University *
}

Review of Food Insecurity and Revolution in the Middle East and North Africa: Agrarian Questions in Egypt and Tunisia, by Habib Ayeb and Ray Bush. (2019). Published by Anthem Press. Available as hardcover, paperback and eBook; 216 pages. Publisher's website: https://www.anthempress.com/food-insecurity-and-revolution-inthe-middle-east-and-north-africa-hb

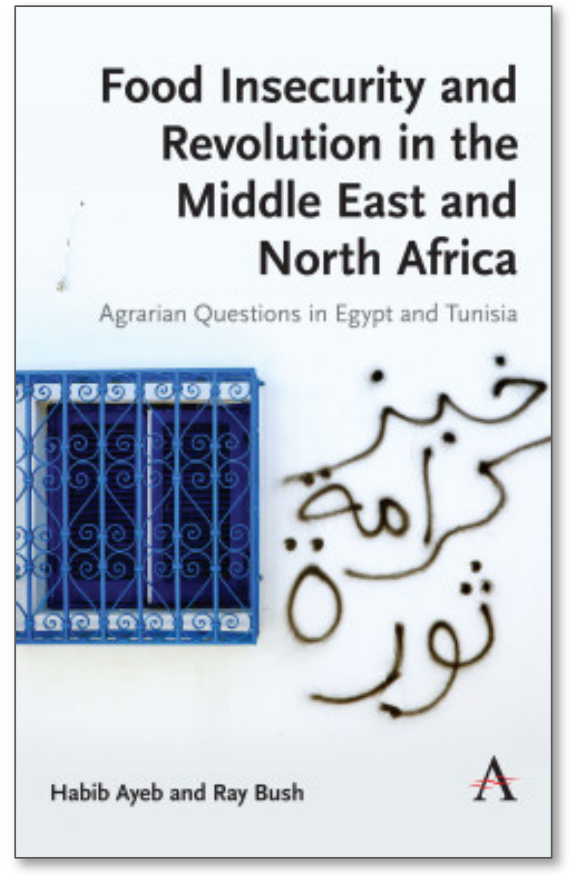

Submitted July 29, 2020 / Published online September 21, 2020

Citation: Shutek, J. R. (2020). Toward a model of food sovereignty in Egypt and Tunisia [Book review]. Journal of Agriculture, Food Systems, and Community Development, 9(4), 343-346. https://doi.org/10.5304/jafscd.2020.094.039

Copyright (C) 2020 by the Author. Published by the Lyson Center for Civic Agriculture and Food Systems. Open access under CC-BY license.

66 ood sovereignty," write Habib Ayeb and Ray 1 Bush, "is a framework and set of policy praxis that prioritises the principle and policies to deliver food as a human right rather than as just another commodity exchanged for cash or kind. People's survival depends on growing and distributing food, which can only be provided in a sustainable way if

\footnotetext{
* Jennifer R. Shutek is a Ph.D. candidate in the Department of Nutrition and Food Studies at New York University and holds a Master of Philosophy in Modern Middle Eastern Studies from the University of Oxford. She specializes in sensory ethnography, urbanism, aesthetics, and gastrodiplomacy, and focuses on foodways in Palestine/Israel. She can be contacted at 1rs758@nyu.edu
}

it is made part of national and public sovereignty" (2019, p. 150). This insight lands with particular poignancy in the context of the 2020 COVID-19 pandemic, when urban and rural communities across the globe face issues of food access and agricultural laborers are constantly exposed to COVID threats in order to continue supplying consumers with produce (Wozniacka, 2020). Ayeb and Bush's monograph thus centers around food sovereignty, a concept which advocates for not only access to food, but the ability of producers and consumers to participate in decisions around what is produced and how it is produced and consumed (La Via Campesina, 2003). 
In Food Insecurity and Revolution in the Middle East and North Africa, Habib Ayeb and Ray Bush undertake the ambitious project of surveying and analyzing data on agrarian systems in Egypt and Tunisia from the 1800s to the present moment. They argue that policies on farming and agriculture, both in the Middle East and North Africa (MENA) and internationally, often occlude farmers' voices, and that Egypt and Tunisia have been incorporated into the world economy in ways that have negatively affected small-scale farmers. A focus on exportdriven economies, cash and monocropping, nationalization and collectivization of agricultural land, and adjustment programs driven by international financial institutions, especially the World Bank and USAID, undermine family farms and peasant livelihoods in Egypt and Tunisia.

Ayeb and Bush draw their data predominantly from secondary data sets to gain a macrocosmic perspective on the conditions of peasants and agricultural laborers in Egypt and Tunisia, grounding the quantitative data in historical descriptions of decolonization, agrarian reforms, regime changes, and the involvement of global organizations like the World Bank. Their chapters are organized thematically and chronologically.

The first chapters provide the historical contexts for contemporary protest movements in Egypt and Tunisia. Chapter two focuses on conflict, economic and agrarian reform, and environmental issues that have led to food and agricultural "underdevelopment" in Egypt and Tunisia. With impressive attention to historic political events throughout the twentieth century, the authors suggest that the MENA is structured by wars, neoliberal reform, and environmental crises (p. 43). Chapter three looks at the agrarian origins of regime change, with a detailed discussion of the self-immolation of Tunisian fruit vendor Mohamed Bouazizi, widely regarded as a catalytic event for the Tunisian Revolution and, indirectly, for the "Arab Spring" movements throughout the MENA. This chapter argues that peasants and the "near landless" played significant roles in the protests that led to the ousting from power of Ben Ali in Tunisia (in January 2011) and Hosni Mubarak in Egypt (in February 2011) (p. 49). Following this, Ayeb and Bush explore narratives of food security (chapter four) before carrying out extensive analyses of the agrarian roots of social unrest in Egypt and Tunisia (chapters five and six). They conclude with a critique of food security-focused analysis and suggest that, instead, food sovereignty should be the main concern for politicians, activists, farmers, and scholars interested in issues of social justice and food access.

The distinction between food security and food sovereignty lies at the heart of Ayeb and Bush's analyses. Food security focuses on providing enough food for populations, often from a strictly quantitative perspective; as a result, neoliberal food security-oriented approaches to hunger can involve import-oriented solutions and large-scale industrialization of food production, which can, paradoxically, destabilize people's access to sufficient and culturally appropriate food. Food sovereignty, on the other hand, argues that individuals and communities must have agency over which foods are produced, how they are produced, and how they are distributed and consumed (Wittman, 2011).

While Ayeb and Bush cover a wide range of themes, their macrolevel approach, at times, can obscure essential topics that require a more granular approach. For example, the topic of gender could be more fully theorized and closely examined. Ayeb and Bush do note, importantly, that "we are therefore not witnessing a feminisation of agricultural work, but rather its increased visibility. Women have always undertaken activities that are crucial to the functioning of the farm, and household" (p. 115). The discussion of gendered labor is important and merits more than the two pages it receives in the chapter on Tunisian agriculture and the one paragraph in the chapter on Egyptian agriculture.

The authors' aim of critiquing existing modes of development in Egypt and Tunisia by applying a Marxist analysis to peasant alienation from the land, and arguing that alternative methods of development are possible, is laudatory. However, one of the most persistent issues arises when the authors refer to the necessity for "alternative models of development" in Egypt in Tunisia. As they acknowledge, they do not discuss tangible 
viable alternatives (p.13). Given the authors' experience and expertise, they are well situated to make insightful contributions to imagining what these alternative systems could look like, in concrete detail.

Ayeb and Bush might have also examined literature from the field of food studies, where there is ample literature that critically discusses how food production in the Global South is adversely affected by capitalist structures (see, for example, work by James C. Scott, Raj Patel, Barry Estabrook, Seth Holmes, and Margaret Gray). Including literature from the field of food studies in their work would have added nuance to their analyses and strengthened their theoretical engagements with foodways.

The most powerful chapter is perhaps the final chapter on food sovereignty, in which the authors discuss the work of La Via Campesina, an international organization of farmers, peasants, and rural workers established in the 1990s. This organization formulated the concept of food sovereignty as a way to discuss their vision of returning autonomy over food production and consumption from governments and corporations to people and communities (Wittman, 2011). Ayeb and Bush suggest that food sovereignty is a model for potential reform to social justice and food sovereignty movements in Egypt and Tunisia. In this chapter, they most clearly articulate their perspectives on narratives of food security, which focus on the industrialization of food production as ultimately harmful to sustainable, healthy, and culturally appropriate agricultural policies. Ayeb and Bush argue that food sovereignty — which, like the Slow Food movement, calls for supporting small-scale agriculture and supporting biodiversity—returns decision-making about agriculture to those who work the land. In this way, the histori- cal trajectory of agricultural policies in Egypt and Tunisia that have disenfranchised farmers and rural workers and led to decreased food security among local populations could be changed. Their reference to a Tunisian group, Million Rural Women, affiliated with La Via Campesina, would have made a fascinating case study; this suggests the necessity of grounded ethnographic work to better understand the operations of organizations mobilizing for food sovereignty.

Food Insecurity and Revolution in the Middle East will be particularly useful for students and scholars in Middle Eastern area studies, history, or political science who want to incorporate food and agricultural systems into their understandings of the MENA. This book would be an appropriate core text in an undergraduate survey course on political economy in the MENA. It could also provide important supplements to undergraduate and graduate food studies courses, which often focus on the United States, Mexico, and western Europe, by introducing topics of food insecurity, food sovereignty, and agricultural policies in the MENA.

Since the 1980s, scholars from diverse fields, notably Roger Owens in The Middle East and the World Economy, 1800-1914 (1981), Sidney Mintz in Sweetness and Power: The Place of Sugar in Modern History (1986), and Raj Patel in Stuffed and Starved: The Hidden Battle for the World Food System (2008) have demonstrated how the globalization of trade and economics have adversely impacted food security and food sovereignty among rural and urban populations. Ayeb and Bush contribute to this growing chorus of voices within and outside of the academy arguing that food insecurity is not reducible to environmental factors alone; rather, food insecurity is often a state created by policy and exacerbate by socio-economic inequalities.

\section{Reference}

La Via Campesina. (2002, January 15). Food Sovereignty. La Via Campesina International Peasant's Movement.

https://viacampesina.org/en/food-sovereignty/

Mintz, S. (1986). Sweetness and power: The place of sugar in modern bistory. New York: Penguin Group.

Owens, R. (1981). The Middle East and the world economy, 1800-1914. New York and London: Methuen \& Co.

Patel, R. (2008). Stuffed and starved: The hidden battle for the world food system. New York: Melville House.

Wittman, H. (2011). Food sovereignty: A new rights framework for food and nature. Environment and Society, 2(1), 87-105. https://doi.org/10.3167/ares.2011.020106 
Journal of Agriculture, Food Systems, and Community Development ISSN: 2152-0801 online https://www.foodsystemsjournal.org

Wozniacka, Gosia. (2020, March 25). Farmworkers are in the coronavirus crosshairs [Blog post]. Civil Eats. https:/ / civileats.com/2020/03/25/ farmworkers-are-in-the-coronavirus-crosshairs 